\title{
Analysis of the Impact of Europe and Central Asia on the Economic Development of Russia
}

\author{
Smirnov V.V. \\ Department of Industrial Economics \\ I.N. Ulyanov State University, Cheboksary \\ Russia \\ walera712006@mail.ru
}

\author{
Osipov D.G. \\ Life safety and engineering ecology Department \\ I.N. Ulyanov State University, Cheboksary \\ denps@mail.ru
}

\author{
Babaeva A.A. \\ I.N. Ulyanov State University, Cheboksary \\ Russia \\ any9196@yandex.ru
}

\begin{abstract}
Subject of the study is influence of Europe and Central Asia on the economic development of Russia. The goal of the study is to determine the factors that significantly influence the economic development if Russia by means of the dynamic range analysis complex and the growth rates of the Europe and Central Asia countries' economies. The study is based on the system approach and application of statistical, cluster and nonparametric analysis methods. The article presents relevance of the study, considers retrospective of scientific and technical cooperation between the countries of Europe and Central Asia. As a result of complex assessment of the European and Central Asia economic development countries dynamic range there has been discovered stability of relations with Austria and Belgium. Russia having low density of population is close to the group of stable countries in terms of unemployment rate and is far behind in terms of GDP per capita. Russia is in the same cluster with Germany which interest is focused on Armenia and Kazakhstan. The significant risks for recession occurring in Germany may affect the economic development of Russia. The dynamics of the of Europe and Central Asia countries economic development is determined by the difference in the degree of competition that is to significant extent caused by the difference in population density and the amount of minerals. Russia located both in Europe and Asia has a tremendous amount of various natural resources and low density of population. Russia applying the European knowledge and technologies and the minerals of Central Asia can ensure stable high rates of economic growth and high level of well-being without consuming its own natural resources. The results of the study are of interest for the public authorities in Europe and Central Asia for selection and substantiation of international cooperation areas.
\end{abstract}

\section{CCS CONCEPTS}

-Scientific and technical cooperation between the countries of Europe and Central Asia $\rightarrow$ Comprehensive assessment of the economic development dynamic range clustering of Russian relations with European countries $\rightarrow$ European knowledge and technology $\rightarrow$ minerals of Central Asia $\rightarrow$ Stable high rates of economic growth in Russia;
Keywords-dynamic range; Europe and Central Asia; cluster; complex analysis; international scientific and technical cooperation; recession; growth rates; economic development.

\section{INTRODUCTION}

Actual researches of Russia economic development in the context of Europe and Central Asia countries is related to its intermediate economic and geographical position in relation to the developed and developing countries.

The reasons that the countries of Europe to the great extent are developed lies in the significant competition related to high density of population per $10 \mathrm{mln} . \mathrm{km}^{2}$ that is about 750 $\mathrm{mln}$. people (population density of $75 \mathrm{mln}$. people per $\mathrm{km}^{2}$ ), which is about $10 \%$ of the population of Earth) [1], to the insignificant quantity but quite a variety of minerals. A positive geographical aspect for development of economy is the location of Europe mainly in the temperate climate with a predominance of plains and mountains occupying only about $17 \%$ of the territory.

Area of Central Asia is $4006253 \mathrm{~km}^{2}$, Central Asia population density is about 36 people per $\mathrm{km}^{2}$. Central Asia comprises desert and semi-desert plains, highlands and plateaus. The climate is sharply continental, dry, temperature fluctuations are significant. Central Asia is reach with natural resources - oil, gas, coal and uranium [2].

Europe exceeds Central Asia almost two times in terms of area and population density. In the existing economic and geographical architecture of the European countries [3, 4, 5] and Central Asia [6, 7, 8] Russia located in Europe and Asia has enormous potential (territory - $17125191 \mathrm{~km}^{2}$, population density -8.56 people per $\mathrm{km}^{2}$, GDP per capita in 2018 according to the IMF amounted to 9264.27 USD - 73rd place in the world) for economy development. 
support; establishment of joint research centers and organizations.

Since adoption in June 2007 of the "Strategies of EU and Central Asia: new partnership" the EU intensified its relations with the whole region. The strategy is supported by a significant increase of the EU regions technical assistance to support cooperation in the field of tertiary education and academic and student exchange programs in the framework of the new fund Erasmusmundus and TEMPUS. On the July 7 , 2019 at the 15-th Ministerial meeting of the EU and Central Asia (in the town of Bishkek, Kyrgyz Republic) the UE adopted a project of a New Strategy for Central Asia named "The EU and Central Asia: New Opportunities for a Stronger Partnership") where the following blocks were highlighted [16]: "Partnership for sustainability", "Partnership for prosperity"; "Focus of the current support".

In the EECA Russia represented the highest quota for R\&D in 2008 and in terms of purchase power parity it corresponded to Canada, India or Italy. In Russia the R\&D activities are mainly funded from the state budget and the dificit resources are concentrated in the social sector characterized by poor results of $R \& D$ commercialization.

Despite the intention of the political elite to consider the innovation-oriented R\&D programs as of highest priority and to support diversification of economy that extends beyond commodity production the results of $R \& D$ activities in the business enterprise segment remain poor. Even in Russia the number of small innovative companies is considerably limited. Small and medium companies still can't become a driver of innovations and large companies carry out the biggest part of innovational activities [16].

\section{RESEARCH METHODOLOGY}

Assessment of the economy development dynamic range (Dynamic Range of Economic Development, DRED) of the Europe and Central Asia countries would be made using the statistical, cluster and non-parametric analysis of the global database "CEIC Data's Global Database": GDP per capita; industrial production index growth; foreign direct investments (FDI); consumer price index (CPI); unemployment rate.

Statistical analysis is a method of collecting, studying and representation of large volumes of data in order to identify the main patterns and tendencies of a certain phenomenon. There are distinguished several methods:

- statistical observation - systematic collection of data followed by mathematical processing;

- sampling - use of a certain part of data on certain grounds (stratified, cluster, quota, etc.);

- correlation and regression - identifies interrelations of data and the reasons why the data depend on each other;

- dynamic - allows to track the strength, intensity and frequency of changes in objects and phenomena. It is necessary to have knowledge of mathematical statistics to carry out qualitative statistical research. scientific and technical cooperation included: exchange of scientific and technical knowledge; financial and technical 
DRED (Dynamic Range of Economic Development) statistical analysis is based on application of the formula

where $\max$ and $\min$ - maximum and minimum value of economy development.

Cluster analysis is a multi-dimensional statistical procedure for collecting of data containing information on objects sampling and ordering of study objects in relatively homogenous groups. The clustering problem belongs to statistical analysis.

Cluster analysis allows to develop a typology or classification of studied objects or phenomena; to identify the main schemes of objects (phenomena) grouping; to formulate hypotheses on the basis of data study; to check a hypothesis or a study to determine eligibility existence of a group distinguished by this or that means from the available data, etc.

DRED cluster analysis using the SPSS Statistics application package (hierarchic cluster analysis, average distance between clusters, squared Euclidean distance).

Non-parametric analysis includes descriptive statistics and statistical input. Non-parametric analysis in the meaning of statistics over data is defined as a function over samples, doesn't depend on a parameter which interpretation doesn't depend on the whole corresponding to any parametrized distributions. Non-parametric statistical hypotheses pay attention to behavior of observed random variables. Nonparametricity value covers the methods that do not assume that model structure is fixed and that model size increases as data complexity growth.

DRED non-parametric analysis - SPSS Statistics (Kholmogorov's agreement criterion, significance level is $0.05)$.

\section{ANALYSIS}

As a result of DRED statistical analysis (according to formula 1) of the Europe and Central Asia countries (Table I) there have been revealed the countries with stable development $(0<$ DRED $<1)$ :

- of GDP per capita - EU, Mongolia, Luxembourg and Cyprus;

- industrial production index growth - Croatia, Estonia, Turkey, Romania, Norway, Austria, Tajikistan, Lithuania, Poland, Georgia, Albania, Finland, Great Britain, Belarus, Armenia, Belgium and Kyrgyzstan;

- foreign direct investments (FDI) - Poland, Luxembourg, Belgium, Netherlands, Latvia, Italy, Switzerland, Estonia, Portugal, Lithuania, UK, Kyrgyzstan, Austria, Czech Republic, France, Kazakhstan and Bulgaria;

- consumer priced index - Switzerland;

- unemployment rate - EU, Azerbaijan, Armenia, France, Albania, Montenegro, Tajikistan, Belgium, Turkey, Austria, Serbia, Mongolia, Kosovo, Macedonia, Romania, Italy,
Netherlands, Malta, Denmark, Croatia, Kazakhstan, Ukraine, Slovenia.

TABLE I. DYNAMICAL RANGE OF THE EUROPE AND CENTRAL ASIA COUNTRIES ECONOMIES DEVELOPMENT

\begin{tabular}{|c|c|c|c|c|c|}
\hline Country & $\begin{array}{l}\text { GDP } \\
\text { per } \\
\text { capit } \\
\text { a }\end{array}$ & $\begin{array}{c}\text { Industrial } \\
\text { productio } \\
\text { n index } \\
\text { growth }\end{array}$ & $\begin{array}{c}\text { Direct } \\
\text { foreign } \\
\text { investmen } \\
\text { ts }\end{array}$ & $\begin{array}{c}\text { Consum } \\
\text { er price } \\
\text { index }\end{array}$ & $\begin{array}{c}\text { Unemployme } \\
\text { nt rate }\end{array}$ \\
\hline $\mathrm{EU}$ & 0.7 & -0.9 & -2.0 & 1.5 & 0.6 \\
\hline Austria & 4.3 & 0.3 & 0.8 & 1.9 & 0.6 \\
\hline Azerbaijan & 4.4 & -0.2 & 2.9 & & 0.3 \\
\hline Albania & 3.3 & 0.6 & 10.7 & & 0.4 \\
\hline Armenia & 3.0 & 0.7 & 1.8 & 1.6 & 0.3 \\
\hline Belarus & 2.1 & 0.7 & 2.2 & 3.9 & 1.9 \\
\hline Belgium & 3.8 & 0.7 & 0.1 & 1.6 & 0.5 \\
\hline Bulgaria & 2.4 & -0.1 & 1.0 & 5.6 & 1.5 \\
\hline $\begin{array}{l}\text { Great } \\
\text { Britain }\end{array}$ & 3.7 & 0.6 & 0.8 & 5.1 & 1.3 \\
\hline Hungary & 3.4 & -0.3 & -0.1 & 3.8 & 1.2 \\
\hline Germany & 2.9 & -0.3 & 1.6 & 2.4 & 1.3 \\
\hline Greece & 4.1 & -0.1 & 1.8 & 0.0 & 1.3 \\
\hline Georgia & 2.1 & 0.5 & 3.7 & 2.4 & 4.5 \\
\hline Denmark & 3.9 & -0.3 & -0.1 & 3.5 & 0.9 \\
\hline Iceland & 3.9 & 1.4 & -0.5 & 2.8 & 1.1 \\
\hline Spain & 4.5 & -0.1 & 1.0 & 3.7 & 1.8 \\
\hline Italy & 4.3 & -0.2 & 0.2 & 2.8 & 0.8 \\
\hline Kazakhstan & 3.0 & 1.1 & 0.9 & 1.6 & 1.0 \\
\hline Cyprus & 0.9 & -0.2 & 2.3 & 1.4 & 1.7 \\
\hline Kosovo & 1.4 & & 3.6 & & 0.7 \\
\hline Kyrgyzstan & 1.6 & 1.0 & 0.8 & & 3.9 \\
\hline Latvia & 2.1 & -0.2 & 0.2 & 1.3 & 1.4 \\
\hline Lithuania & 2.8 & 0.4 & 0.8 & 2.3 & 1.5 \\
\hline $\begin{array}{l}\text { Luxembour } \\
\mathrm{g}\end{array}$ & 0.9 & -0.3 & 0.1 & 1.2 & 1.2 \\
\hline Macedonia & 1.3 & -0.3 & 1.5 & & 0.8 \\
\hline Malta & 1.1 & -0.3 & 1.7 & 2.3 & 0.9 \\
\hline Moldova & 2.3 & -0.3 & 2.5 & 6.0 & 1.9 \\
\hline Mongolia & 0.5 & 1.4 & -2.0 & & 0.7 \\
\hline $\begin{array}{c}\text { Netherland } \\
\text { s }\end{array}$ & 4.0 & -0.3 & 0.2 & 5.1 & 0.8 \\
\hline Norway & 6.3 & 0.2 & -0.3 & 2.3 & 1.0 \\
\hline Poland & 2.4 & 0.4 & 0.0 & 3.7 & 1.7 \\
\hline Portugal & 4.2 & -0.1 & 0.6 & 2.0 & 1.3 \\
\hline Russia & 3.5 & & 2.3 & 2.3 & 1.2 \\
\hline Romania & 2.5 & 0.2 & 1.8 & 6.2 & 0.8 \\
\hline Serbia & 1.5 & 0.0 & 3.3 & 3.5 & 0.6 \\
\hline Slovakia & 1.7 & -0.2 & -0.1 & 5.0 & 1.2 \\
\hline Slovenia & 1.5 & -0.6 & 1.1 & 2.1 & 1.0 \\
\hline Tajikistan & 2.4 & 0.3 & -0.9 & & 0.4 \\
\hline Turkey & 1.4 & 0.2 & 2.3 & 2.4 & 0.6 \\
\hline Ukraine & 1.9 & -0.5 & 2.6 & 10.8 & 1.0 \\
\hline Finland & 3.8 & 0.6 & -0.9 & 1.7 & 1.8 \\
\hline France & 3.6 & -0.9 & 0.9 & 2.8 & 0.4 \\
\hline Croatia & 1.2 & 0.1 & 1.2 & 1.4 & 1.0 \\
\hline $\begin{array}{c}\text { Montenegr } \\
\text { o }\end{array}$ & 1.7 & 0.0 & 2.3 & 1.1 & 0.4 \\
\hline $\begin{array}{c}\text { Czech } \\
\text { Republic }\end{array}$ & 2.1 & -0.4 & 0.9 & 3.9 & 1.5 \\
\hline $\begin{array}{c}\text { Switzerlan } \\
\mathrm{d}\end{array}$ & 1.7 & & 0.4 & 0.7 & 1.3 \\
\hline Sweden & 3.6 & 1.7 & 1.4 & 3.9 & 2.1 \\
\hline Estonia & 3.0 & 0.1 & 0.5 & & 3.7 \\
\hline
\end{tabular}

Source: calculated using formula (1) according to the "CEIC Data's Global Database".https://www.ceicdata.com

Overall stability of DRED by GDP per capita, industrial production index growth, foreign direct investments (FDI), 
consumer price index (CPI), unemployment rate is seen in Austria and Belgium.

TABLE II. CLUSTER ANALYSIS OF THE EUROPE AND CENTRAL ASIA COUNTRIES ECONOMIES DYNAMIC RANGE DEVELOPMENT INDEXES

\begin{tabular}{|c|c|c|}
\hline \multicolumn{2}{|c|}{ United cluster } & Square of Euclidean distance \\
\hline \multirow{5}{*}{ EU } & Mongolia & 7.6 \\
\hline & Austria & 23.1 \\
\hline & Georgia & 25.9 \\
\hline & Ukraine & 81.5 \\
\hline & Albania & 110.9 \\
\hline \multirow{9}{*}{ Austria } & Portugal & 0.7 \\
\hline & Italy & 1.2 \\
\hline & Belgium & 1.9 \\
\hline & Iceland & 3.7 \\
\hline & Armenia & 5.1 \\
\hline & Great Britain & 8.3 \\
\hline & Norway & 12.3 \\
\hline & Belarus & 14.6 \\
\hline & Azerbaijan & 17.1 \\
\hline \multirow{3}{*}{ Azerbaijan } & Greece & 2.5 \\
\hline & Cyprus & 13.3 \\
\hline & Kyrgyzstan & 14.5 \\
\hline \multirow{2}{*}{ Armenia } & Kazakhstan & 2.3 \\
\hline & Germany & 2.7 \\
\hline \multirow{2}{*}{ Belarus } & Serbia & 3.9 \\
\hline & Bulgaria & 8.3 \\
\hline \multirow{2}{*}{ Bulgaria } & Romania & 1.7 \\
\hline & Moldova & 2.3 \\
\hline \multirow{4}{*}{ Great Britain } & Netherlands & 1.4 \\
\hline & Hungary & 4.1 \\
\hline & Poland & 5.6 \\
\hline & Sweden & 7.4 \\
\hline \multirow{3}{*}{ Hungary } & Denmark & 0.4 \\
\hline & France & 2.6 \\
\hline & Spain & 3.2 \\
\hline Germany & Russia & 1.1 \\
\hline Iceland & Finland & 2.6 \\
\hline Kazakhstan & Lithuania & 1.4 \\
\hline \multirow{3}{*}{ Cyprus } & Malta & 2.5 \\
\hline & Latvia & 4.3 \\
\hline & Kosovo & 8.7 \\
\hline Kyrgyzstan & Estonia & 2.7 \\
\hline \multirow{3}{*}{ Latvia } & Switzerland & 0.7 \\
\hline & Luxembourg & 1.3 \\
\hline & Macedonia & 3.6 \\
\hline \multirow{3}{*}{ Malta } & Slovenia & 0.7 \\
\hline & Croatia & 1.2 \\
\hline & Turkey & 2.2 \\
\hline Mongolia & Tajikistan & 6.1 \\
\hline \multirow{2}{*}{ Poland } & Czech Republic & 1.6 \\
\hline & Slovakia & 2.8 \\
\hline Turkey & Montenegro & 1.7 \\
\hline
\end{tabular}

Note: Hierarchical cluster analysis. The average distance between clusters, the square of the Euclidean distance.

Source: calculated in "SPSS Statistics" according to the "CEIC Data's Global Database".https://www.ceicdata.com

Austria (capital - Vienna) is the most developed industrial and agricultural country among the countries of Europe that have population density over 100 people per $\mathrm{km}^{2}$ (advantages - chemical and petrochemical and textile industry, electrical engineering, wood processing; qualified workforce; tourism; disadvantages - dependence on imported raw materials (oil and gas)).
Belgium (capital - Brussels) -the most important manufacturer or metal products and textiles, leading region in the industry 4.0, world center of diamond trade, highly developed chemical industry, educated and motivated workforce with featuring high productivity, population density of over 370 people per $\mathrm{km}^{2}$.

Russia (with population density of over 8 people per $\mathrm{km}^{2}$ ) is as close as possible to the stable countries group only in terms of low unemployment level and is far behind them in terms of GDP per capita.

As a result of DRED cluster analysis of the Europe and Central Asia countries (Table II) there is revealed a large, stable cluster with the participation of Austria, Belgium, Portugal, Italy, Iceland, Armenia, Great Britain, Norway, Belarus and Azerbaijan.

Russia "anchored" in the united cluster with Germany.

As a result of DRED non-parametric analysis of the Europe and Central Asia countries there was detected deviation of the hypothesis 'Ukraine with the minimum of 3,163 and maximum of 4.40" and acceptance of a hypothesis "GDP per capita with the minimum of 2.673 and maximum of 1.26).

For Russia the significance of DRED by GDP per capita indicates forecast perspectives of volatile (Russia, $\sigma^{2}=0.16$, trend $-\mathrm{y}=0.0001 \mathrm{x}^{3}-0.0073 \mathrm{x}^{2}+0.1451 \mathrm{x}-0.2161, \mathrm{R}^{2}=$ $0.9083)\left(\mathrm{OECD}, \sigma^{2}=0\right.$, trend $-\mathrm{y}=0.0775 \ln (\mathrm{x})+1.6688, \mathrm{R}^{2}$ $=0.9607 ;$ World, $\sigma^{2}=0.12$, trend $-\mathrm{y}=-0.39 \ln (\mathrm{x})+3.4929$, $\left.\mathrm{R}^{2}=0,9488\right)$, low median (Russia, $\left.\mathrm{Me}=0.76\right)(\mathrm{OECD}, \mathrm{Me}=$ 1.89; World, $\mathrm{Me}=2.3$ ) growth rates of real GDP in relation to stable countries of Europe and Central Asia including OECD, of the whole OECD and World.

Analysis of the DRED assessment results of the Europe and Central Asia countries revealed stability:

- of investment attractiveness - growth of industrial production index and FDI: Austria, Belgium, Great Britain, Kyrgyzstan, Lithuania, Poland and Estonia;

- active application of innovative products: growth of industrial production index and unemployment level: Austria, Albania, Armenia, Belgium, Romania, Tajikistan, Turkey and Croatia.

Overall stability of DRED by GDP per capita, industrial production index growth, foreign direct investments (FDI), consumer price index (CPI), unemployment rate is seen in Austria and Belgium.

Russia is significantly behind EU, Mongolia, Luxembourg and Cyprus in terms of GDP per capita but is close enough to them in terms of unemployment rate. This situation characterizes the extensive way of development - low level of automation and staff qualification [17]. Russia is trying to raise the level of automation and step into the era of "Industry $4.0 "$ in a joint cluster with Germany. It is more interested in cooperation with Armenia and Kazakhstan. As a result, Russia is expected to have volatile low-median real GDP growth rates relative to stable countries in Europe and Central Asia, including the OECD, the whole OECD and the World. 
investigation of the flagrantly famous investment fund of Malaysia named 1MDB.

Economy of Russia taking into account the time lag would sense the corresponding negative impact not only from Germany but also the USA in the near future. The following measures would help to reduce the negative effect of Russia cooperation with Germany and others: strengthening of international cooperation with Germany in the terms of R\&D (private and public research organizations) [23] development of joint research institutes; increase of Russian human potential [24], improving the quality of scientific knowledge transfer from German society to Russian; promotion and dissemination of European standards of higher education (Bologna principles), which will facilitate international mobility of students and researchers; formation of joint competitive programs of innovations funding; creation of the Russian national innovation system, etc.

\section{CONCLUSIONS}

Dynamics of the Europe and Central Asia countries economies development is determined by the difference in competition level that is significantly defined by the difference in population density of 75 and 36 persons per $\mathrm{km}^{2}$ correspondingly and also by the amount of minerals. Unlike Europe the Central Asia is reach with oil, gas, coal, uranium.

Russia being located in Europe and Asia has a tremendous amount of various natural resources and low density of population of 8.56 persons per $\mathrm{km}^{2}$ showing an indecently low GDP per capita (73rd place in the world, behind Mexico and Surinam).

Russia applying the European knowledge and technologies and the minerals of Central Asia can ensure stable high rates of economy growth and high level of well-being without consuming its own natural resources.

Collapse of the Soviet Union led to competition intensification in the Eurasian space. This was facilitated by removal of internal and foreign trade limitations. Challenges of global trade and multi-lateral trade system development intensified after restructuring of the international economic order, changes in cross-sectoral terms of trade and global interest rates. Against this background, a new global financial system is emerging, driven by outsourcing and vertical specialization.

Resource and technological characteristics of the Europe and Central Asia countries economies come to the fore determining the conditions for maintaining high rates of global GDP growth.

After collapse of the USSR the international cooperation in terms of R\&D began to play the key role in implementation of national strategies in all the countries of EECA.

DRED complex assessment using statistical analysis (author's formula), cluster and non-parametric analysis of CEIC Data's Global Database showed stability of DRED by GDP per capita, by growth of industrial production index, FDI, CPI, unemployment rate for Austria and Belgium. Russia with its low population density is close to the group of stable 
and Society, 2011, vol. 4, iss. 1, pp. 13-27, https://doi.org/10.1093/cjres/rsq014

countries only in terms of unemployment rate and is significantly behind them in terms of GDP per capita.

There has been discovered a large stable cluster comprising Austria, Belgium, Portugal, Italy, Iceland, Armenia, Great Britain, Norway, Belarus and Azerbaijan. Russia "anchored" in the united cluster with Germany that is more interested in cooperation with Armenia and Kazakhstan.

In the "USA - Eastern Asia - Europe" triangle Germany may become a partner of Russia for dynamic growth that is determined by long-term forecast of real GDP growth. The significant risks of recession occurring in Germany against the background of the USA pressure on the EU (lobbying for lower taxation of American technology companies income) may lead to problems in development of the Russian economy.

\section{References}

[1] S. Moriconi, G. Peri. "Country-specific preferences and employment rates in Europe". European Economic Review, 2019, vol. 116, pp. 1-27, https://doi.org/10.1016/j.euroecorev.2019.03.008

[2] "TrendEconomy". http://data.trendeconomy.ru

[3] N. Mikova, W. Eichhammer, B. Pfluger. "Low-carbon energy scenarios 2050 in north-west European countries: Towards a more harmonised approach to achieve the EU targets". Energy Policy, 2019, vol. 130, pp. 448-460, https://doi.org/10.1016/j.enpol.2019.03.047

[4] R. P. Pradhan, M. B. Arvin, M. Nair, S. E. Bennett, S. Bahmani. "Short-term and long-term dynamics of venture capital and economic growth in a digital economy: A study of European countries". Technology in Society, 2019,vol. 57, pp. 125-134, https://doi.org/10.1016/j.techsoc.2018.11.002

[5] R. P. Maradana, R. P. Pradhan, S. Dash, D. B. Zaki, A. K. Sarangi. "Innovation and Economic Growth in European Economic Area Countries: The Granger Causality Approach”. IIMB Management Review, In press, accepted manuscript, Available online 3 April 2019, https://doi.org/10.1016/j.iimb.2019.03.002

[6] A. Mazhikeyev, T. H. Edwards, M. Rizov. "Openness and isolation: The trade performance of the former Soviet Central Asian countries". International Business Review, 2015,vol. 24, iss. 6, pp. 935-947, https://doi.org/10.1016/j.ibusrev.2015.03.001

[7] J.-X. Li, Y.-N. Chen, C.-C. Xu, Z. Li. "Evaluation and analysis of ecological security in arid areas of Central Asia based on the emergy ecological footprint (EEF) model". Journal of Cleaner Production, 2019, vol. 235, pp. 677,https://doi.org/10.1016/j.jclepro.2019.07.005

[8] H. Guo, A. Bao, T. Liu, G. Jiapaer, F. Ndayisaba, L. Jiang, A. Kurban, P. D. Maeyer. "Spatial and temporal characteristics of droughts in Central Asia during 1966-2015". Science of The Total Environment, 2018,vol. 624 ,

pp. $1523-1538$, https://doi.org/10.1016/j.scitotenv.2017.12.120

[9] M. Suesse. "Breaking the Unbreakable Union: Nationalism, Disintegration and the Soviet Economic Collapse". The Economic Journal, 2018, vol. 128, iss. 615, pp. 2933-2967. https://doi.org/10.1111/ecoj.12564

[10] J. K. Galbraith. "Inequality and economic and political change: a comparative perspective". Cambridge Journal of Regions, Economy
[11] D. S. Bieri."Financial stability, the Basel Process and the new geography of regulation". Cambridge Journal of Regions, Economy and Society, 2009,vol. 2, iss. 2, pp. 303-331, https://doi.org/10.1093/cjres/rsp004

[12] L. Agnello, G. Fazio, R. M. Sousa. "National fiscal consolidations and regional inequality in Europe". Cambridge Journal of Regions, Economy and Society, 2016, vol. 9, iss. 1, pp. 59-80, https://doi.org/10.1093/cjres/rsv033

[13] F. Ploeg, S. Poelhekke. "Globalization and the rise of mega-cities in the developing world". Cambridge Journal of Regions, Economy and Society, 2008,vol. $1, \quad$ iss. 3 , pp. 477-501, https://doi.org/10.1093/cjres/rsn008

[14] L. Dijkstra. "Why investing more in the capital can lead to less growth Cambridge Journal of Regions, Economy and Society", 2013,vol. 6, iss. 2, pp. 251-268, https://doi.org/10.1093/cjres/rst009

[15] K. Schuch, G. Bonas, J. Sonnenburg. "Enhancing science and technology cooperation between the EU and Eastern Europe as well as Central Asia: a critical reflection on the White Paper from a S\&T policy perspective". Journal of Innovation and Entrepreneurship. 2012. 1:3. https://doi.org/10.1186/2192-5372-1-3

[16] New EU Strategy for Central Asia and the Caspian Region.AbdullinDimash, expert - analyst. http://casp-geo.ru

[17] V.V. Smirnov, D.G. Osipov, A.A. Babaeva, E.V. Grigorieva, E.F. management system". Proceedings of the 1st International Scientific Conference "Modern Management Trends and the Digital Economy: from Regional Development to Global Economic Growth" (MTDE 2019). Pp. 22-27. https://doi.org/10.2991/mtde-19.2019.5

[18] V. Smirnov, V. Semenov, E. Kadyshev, A. Zakharova, E. Perfilova. "Management of development efficiency of the Russian Economy" The European Proceedings of Social \& Behavioural Sciences (SCT 2018). Published by the Future Academy. 2019. ISSN: 2357-1330, no. 218 pp.

$1871-1877$ doi:https://dx.doi.org/10.15405/epsbs.2019.03.02.2

[19] A. B. Zubov, N. I. Basovskaya, V. G. Baranovsky, N. K. Arbatova, A. G. Arbatov, G. I. Machavariani, S. V. Utkin, O. Yu. Potemkina, H. V. Steinfeld. "Russia and Western Europe: when did the paths diverge?". World economy and international relations, 2012,no. 5,pp. 8092.(InRuss.)

[20] N. V. Pavlov. "Germany-Russia-EU: a triangle of cooperation or contradictions?". World economy and international relations, 2019, vol 63, no. 3, pp. 67-75,https://doi.org/10.20542/0131-2227-2019-63-5-6775. (In Russ.).

[21] A. A. Nevskaya. "Trade in services: new in relations between Russia and the European Union". World Economy and International Relations. 2019, vol. 63, no. 3, pp. 49-58, https://doi.org/10.20542/0131-22272019-63-3-49-58. (In Russ.)

[22] T. A. Romanova, E. B. Pavlova. "Stress tolerance in the European Union and Russia: the essence and prospects of a new concept". World Economy and International Relations, 2019, vol. 63, no. 6, pp. 102109,https://doi.org/10.20542/0131-2227-2019-63-6-102-109. (In Russ.).

[23] V. G. Varnavsky. "Globalization and structural changes in world production". World Economy and International Relations, 2019, vol. 63, no. 1, pp. 25-33. https://doi.org/10.20542/0131-2227-2019-63-1-2533. (In Russ.). Perfilova "Parity of innovation and digital economy in the Russian 